\title{
Structural and Geochemical Characterization of Gold Mineralized Quartz Veins in Belikombone Gold Prospect, Betare-oya Gold District, East Cameroon
}

\author{
Melvin Tamnta Nforba ${ }^{1}$,, Suka Joe Chi ${ }^{2}$, Tangko Tangko Emmanuel ${ }^{1}$, Arnaud Patrice Kouske ${ }^{3}$ \\ ${ }^{1}$ Geo-Technical Engineering Associates, Inc., Laurel, Maryland, USA \\ ${ }^{2}$ Department of Geology and Mining, Saint Monica University Institute, Buea, Cameroon \\ ${ }^{3}$ Department of Civil Engineering, The University Institute of Technology, University of Douala, Douala, Cameroon
}

Email address:

nforbamel@gmail.com (M. T. Nforba)

${ }^{*}$ Corresponding author

\section{To cite this article:}

Melvin Tamnta Nforba, Suka Joe Chi, Tangko Tangko Emmanuel, Arnaud Patrice Kouske. Structural and Geochemical Characterization of Gold Mineralized Quartz Veins in Belikombone Gold Prospect, Betare-oya Gold District, East Cameroon. Engineering Science.

Vol. 5, No. 2, 2020, pp. 17-26. doi: 10.11648/j.es.20200502.12

Received: August 21, 2019; Accepted: September 17, 2019; Published: May 28, 2020

\begin{abstract}
Au-bearing quartz veins in the Belikombone area are confined to major NW-SE orientations in schists and N-S and ENE - WSW in other host rocks. The objectives of this work were to study field, mineralogy and geochemical characteristics of gold mineralised quartz veins. Schists (chlorite rich) and gneisses (moderately magnetic) are the dominant rock types in the area with granite occurring as intrusions within the gneisses. Gold-bearing quartz veins occur in association with metamorphosed rocks ranging in composition from quartz \pm gold to those that contain quartz \pm gold \pm sulphides \pm ironoxides \pm sericite and mafic minerals. The mineralized veins contain Au from 0.50 to $25 \mathrm{ppm}$, while the quartz veins considered barren contain $0.20 \mathrm{ppm} \mathrm{Au}$. The concentration of As in the quartz veins ranges from $0.30 \mathrm{ppm}$ to $10.70 \mathrm{ppm}$ and it show positive correlation with $\mathrm{Au}$ in samples with high Au concentration. The $\Sigma$ REE varies from 5.79 to 173.64 in the quartz veins. The investigated veins show evidence of multiphase deformation and it is associated with $\mathrm{D}_{2}$ deformation in the area. This structural setting suggest that the emplacement of gold mineralization occurred during the late Pan African orogeny. The main alteration types are silification, sericitization and sulphidation processes.
\end{abstract}

Keywords: Gold, Quartz Veins, Geochemistry, Belikombone, Betare-oya, Cameroon

\section{Introduction}

Quartz vein systems in regions that have experienced deformation remain the main depository for primary $\mathrm{Au}$ [1]. Deformation in these regions occur in stages and the migration of hot fluids (hydrothermal) from the subsurface into the resulting structures also follow the sequence of deformation. These fluids eventually precipitate material into these structures forming lodes and veins that differ in their characteristics $[1,2]$. Veins in such areas show different patterns including fault-fill veins, extensional veins and stockwork-like veins $[3,4]$. Au -bearing veins are usually of polymetallic type with different textural characteristics. Some of these textures are usually associated with ore zones (mineralized veins) while others are found in barren ones [3]. Some of the mineralized textures include overprinting and modification textures including phantom veins, ribbon and brecciated quartz, laminated quartz and comb quartz textures [3]. Goldbearing quartz veins occur in association with metamorphosed rocks ranging in composition from quartz \pm gold to those that contain quartz \pm gold \pm sulphides \pm ironoxides \pm sericite and mafic minerals.

The Belikombone gold prospect is found within the Betare-Oya gold district of the Eastern Cameroon gold fields. General descriptive information on gold mineralization in the Eastern region has been well documented $[5,6]$. In most cases of Au exploration, grade is easily assessed by crushing a quantity of quartz block samples, weighing and panning to obtain the concentrate from which the Au-grains if present, 
can easily be recovered and weighed (e.g. [7-9]. As such, quartz vein systems appear to be a major tool in the study and understanding of the hydrothermal processes as well as the geochemistry of ore deposits that serves as a guide in mineral exploration [3]. Recent fieldworks have revealed an important gold bearing quartz veins in the Belikombone gold prospect and neighborhoods. Those gold occurrences are related to faults and folds, and commonly occur in shear zones.

This paper seeks to examine the field characteristics, petrography, mineralogy and geochemical composition of the quartz veins within the Belikombone area and to establish exploration prediction models. In addition to this, the possible origin of the gold bearing fluid is inferred.

The Belikombone gold district is part of the Lom Series which is a portion of the Neoproterozoic rock unit in Eastern Cameroon. The Neoproterozoic rock unit of Cameroon, north of the Congo craton is part of the Pan-African belt in Central
Africa known as the Central African Fold Belt (CAFB; [10, 11], or North Equatorial Fold Belt (NEFB; [12], which was formed during the Pan-African orogeny. The Lom Series is made up of a NE-SW discontinuous narrow belt (Figure 1) comprising of a Lower and Upper Groups [13]. It represents a syn-tectonic pull-apart basin associated with the Sanaga shear zone and was deposited between 613 and $600 \mathrm{Ma}[13,14]$. The Lower and Upper Lom Series is made up of metatuffs, volcanoclastic and sedimentary derived schists, staurolitegarnet mica schists and quartzites with local conglomerate layers [14]. The schists were metamorphosed under greenschist facies conditions [13]. The volcanoclastic rocks are felsic to intermediate in composition [12 - 14]. The lowpressure (garnet-andalusite-staurolite assemblage) regional metamorphism that was associated with transpressive tectonics in the Lom Series involved a high thermal gradient related to widespread crustal melting that produced the dominant S-type granitoids in the region $[13,14]$.

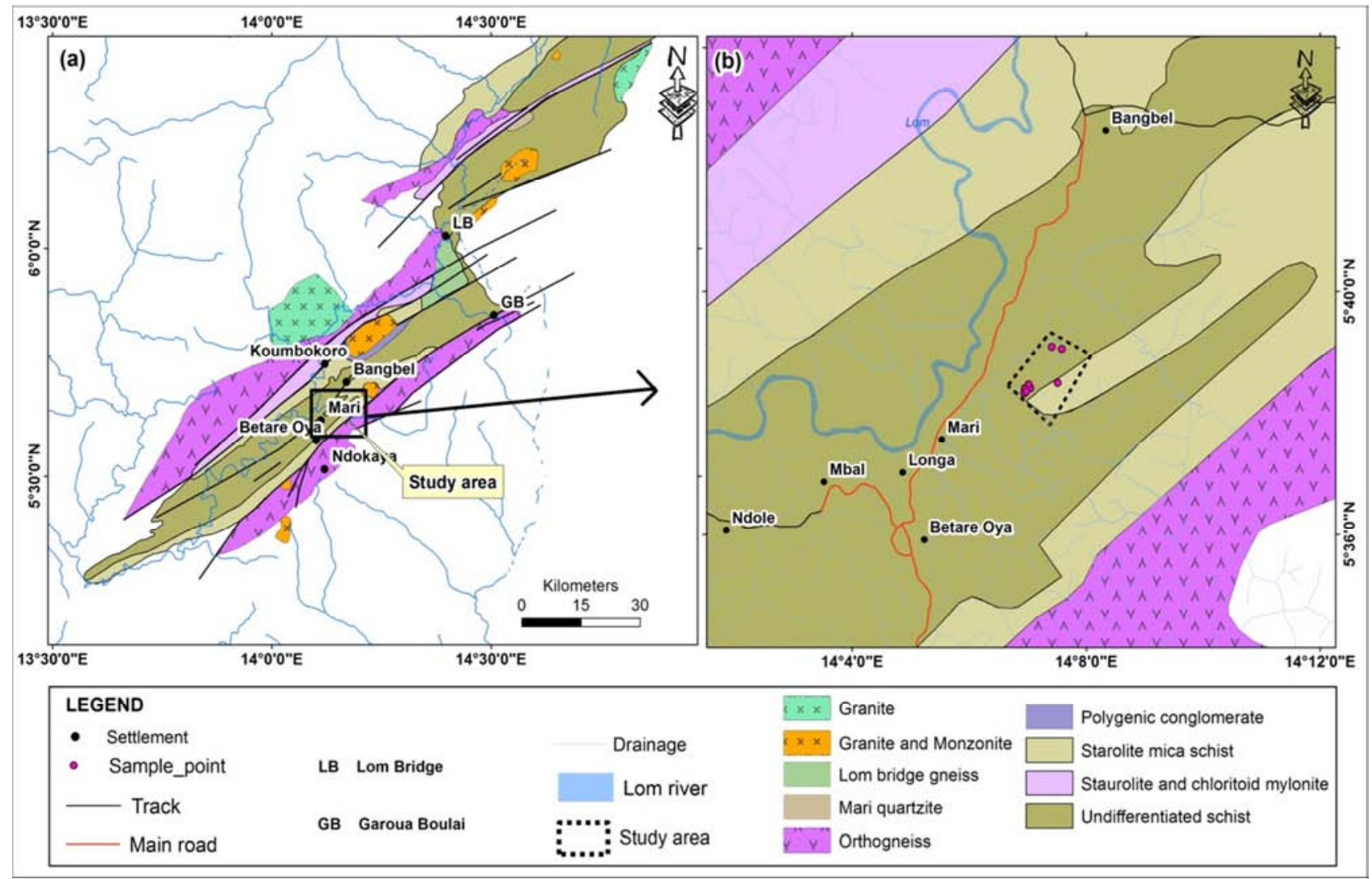

Figure 1. Regional Geologic setting of study area.

The tectono-metamorphic evolution of the Lom Series is polyphase, characterized by two stages of compressional deformation $\left(\mathrm{D}_{1} / \mathrm{D}_{2}\right)$, leading to a N50-N70 steep regional foliation without any apparent stretching lineation $[12,13]$. Dextral or sinistral faults locally parallel to the main foliation characterize the later stages $\left(D_{3}\right)$ of the structural evolution of the Lom Series [13-15]. Simple shear wrenching $\left(D_{3}\right)$ in the Betare-Oya area is geometrically related to the NE-SW striking Betare-Oya shear zone (BOSZ) and to the Sanaga shear zone, with the mylonitic foliation spatially related to the BOSZ [15]. The host rocks are biotite schists, sericite and chlorite schists, quartzites and shales that constitute the Lom Series [6].

The Lom series is well known for its high economic potential which may be explained by the Neoproterozoic reworking and remobilization of an Archean to Palaeoproterozoic basement [13].

\section{Materials and Methods}

Quartz veins were collected as grab samples during structural and lithological mapping of the study area. During 
the lithological mapping structural measurements were taken. Thin sections were manufactured in the laboratory of the Institute of Geological and Mining Research (IGMR) at Nkolbisson, Yaounde, Cameroon, for minerals and microstructure studies. These thin sections were observed under plane and polarized light using an Olympus Cx31 electronic microscope. Petrographic images were snapped using a CMCA61300A camera attached to the microscope.

Quartz veins geochemical analyses (major, trace and rare earth elements) were obtained using Inductively Coupled Plasma Mass Spectrometry (ICP-MS) on the pulp at ALS Mineral Global Group in South Africa. Samples were weighed and dried at $100^{\circ} \mathrm{C}$ to remove the moisture using a space warmer for 12 hours and later crushed in a jaw crusher and pulverized using ESSA ${ }^{\circledR}$ in a tungsten carbidecoated mill to obtain homogeneous samples for the analysis (www.alsglobal.com). Aqua Regia analysis was carried out on $15 \mathrm{~g}$ of each sample pulp. The finely pulverized sample was digested in a mixture of Hydrocholoric acid (HCL) and Nitric acid $\left(\mathrm{HNO}_{3}\right)$. This acid mixture generates nascent chlorine and nitrosyl chloride which will dissolve free gold and gold compounds. A replicate was done after each analysis for quality control and quality assurance with standards and blanks inserted after every 5 samples to calibrate the equipment and ensure optimal precision of the data set obtained at a $95 \%$ confidence level.

\section{Results}

\subsection{Petro-structural Characterization of Quartz Veins and Host Rocks}

Field investigations have revealed that the prospected area is composed of metamorphic and magmatic rocks. These are the host rocks for quartz veins in the area.

\subsubsection{Petrography of Host Rocks}

The metamorphic rocks in the area comprise of schists and gneisses (Figure 2). Schists at Belikombone are dominated by chlorite associated with sericite $(65 \%)$, quartz $(25 \%)$ and oxides $(10 \%)$. Chlorite occurs as thin bands with a lepidoblastic texture (Figure 3e). Gneiss which is moderately magnetic (Figure 3h) display an alternation of whitish (quartzo-feldspathic with more or less muscovite 5\%) and dark bands of variable thickness. The dark bands are dominantly composed of magnetite, biotite, amphibole and oxides. This rock has fine to medium-grained with simple cracks which indicate possible wall rock alterations. The rock displays a granoblastic texture.
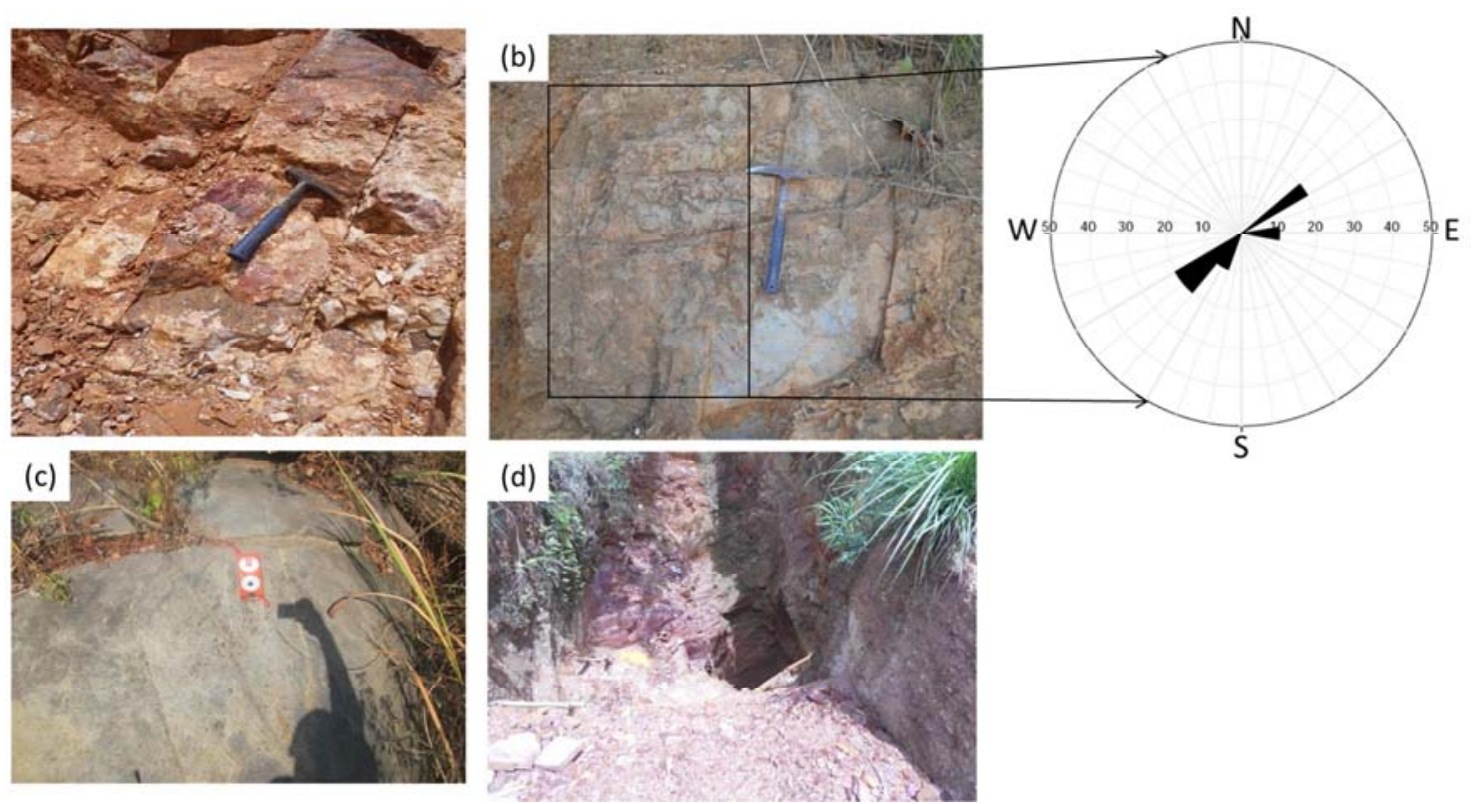

Figure 2. (a) Quartzite, (b) Schist, (c) Granite and (d) pits dug along the trend of quartz vein at Belikombone.

The magmatic rocks in the area are granites (Figure $2 \mathrm{c}$ and Figure $3 \mathrm{f}$ ) which occurred as bouldering intrusions in gneiss, some of which are about $2 \mathrm{~m}$ long and a meter high. The rocks are massive, with medium to coarse grains. The rock is made up of quartz (50\%), plagioclase $(8 \%)$, amphibole $(7 \%)$, oxides $(10 \%)$, biotite $(10 \%)$ and muscovite $(15 \%)$. As a whole, the rock displays a porphyroblastic-like texture showing that this rocks has been deformed.

\subsubsection{Structure}

The schists at Belikombone show well-developed schistosity defined by sericite. Some of the schists are crosscut by both joints and veinlets which intersect each other. Some of the granites have millimetric multi-directional quartz veins exhibiting a stockwork-like structure. These veinlets (averagely $2 \mathrm{~mm}$ thick) also occur as individual microlines (Figure 3f), representing about 35\% of the rock. They are dominantly composed of quartz up to $95 \%$ when viewed using plane polarized light (Figure $3 \mathrm{~g}$ ). In addition to these microstructures, the rocks in the prospected area are cross cut by an important number of quartz veins. The later occur as 
individual or clustered veins with a general NW-SE trend and vary from few centimeter to about $7 \mathrm{~m}$ wide. These structures have been differentiated based on their mineralogical content into mineralized and barren quartz veins (Figure 4). Most of the mineralized veins are massive with multiple fractures on their surfaces; these fractures are filled with oxides (magnetite) (Figure 4a) found in thin pellicles. Mineralogically these quartz veins have approximately $90 \%$ quartz grain, 5\% sulphide and $5 \%$ oxides and show numerous textural features
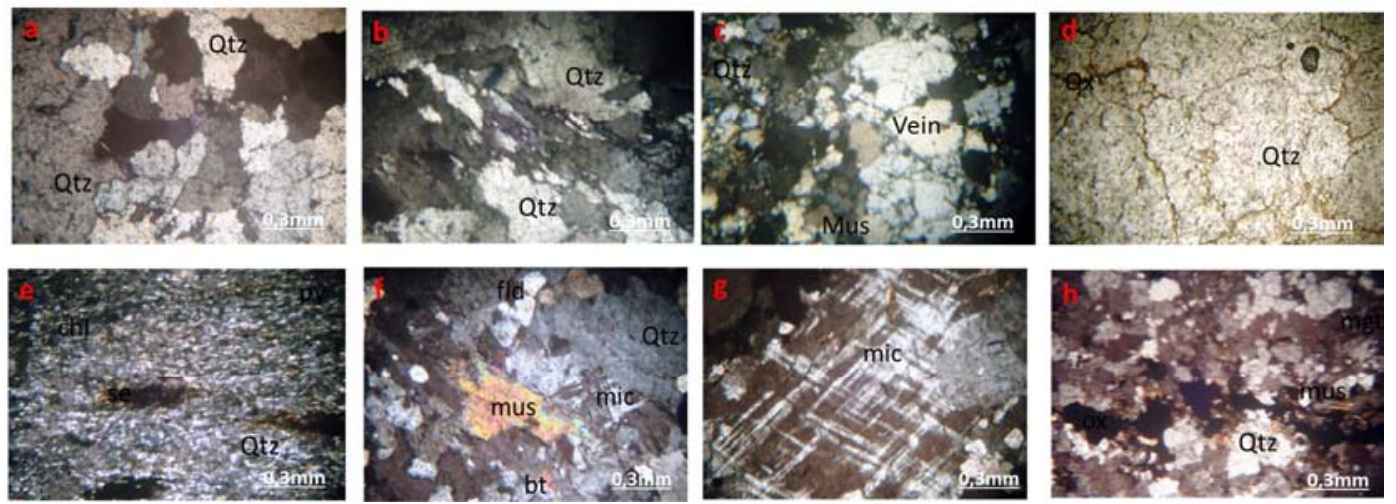

such as porphyroblastic and granoblastic. The relationship between mineralised veins and the host schists suggest an epigenetic style of mineralisation. These veins vary considerably in thickness and often exhibit significant vertical and lateral continuity (Figure 4a). They vary from few centimeter to $5 \mathrm{~m}$ wide with strike values ranging from $\mathrm{N} 006 \mathrm{E}$ to N165E (mean strike of N78E). The dip of the mineralized veins varies from subhorizontal $\left(9^{\circ}\right)$ to vertical $\left(89^{\circ}\right)$ to the NW and SE (Figure 5).

Figure 3. (a-d) Photomicrograph of representative rock samples from the study area. (a-d) Quartzite, (e) Schist, (f) Granit, (g) Microcline and (h) Gneiss.

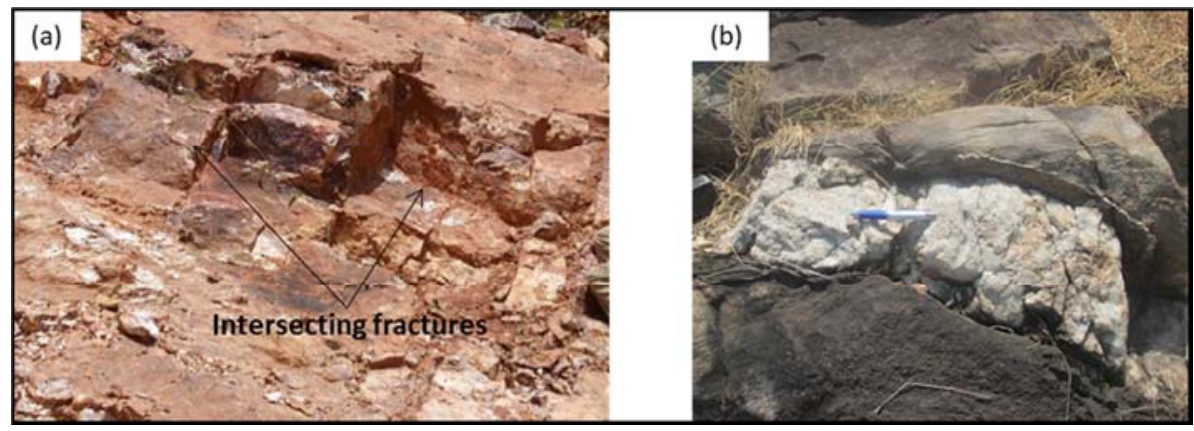

Figure 4. (a) Mineralized vein dissected by intersecting fractures (b) Non-Mineralized vein.
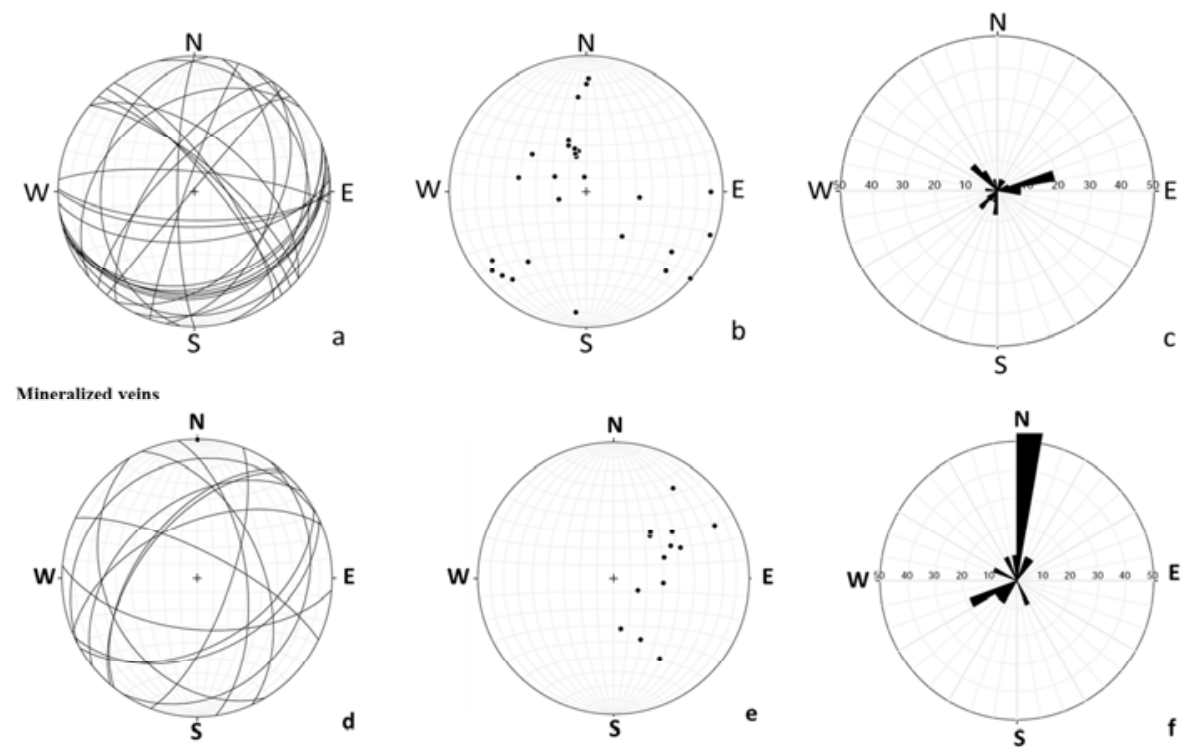

Non-mineralized veins

Figure 5. $\beta$, $\pi$, and Rose diagrams of Mineralized and non-mineralized veins. 
Most of these veins are brecciated with fractured surfaces which are filled with iron oxide. The main gangue mineral in the quartz vein consists of exclusively xenomorphic quartz crystals (more than $98 \%$ of the veins) with an equigranular texture. The proportion of the vein -forming minerals varies from veins that contain only quartz to those containing quartz \pm sulphides \pm iron-oxides \pm sericite. In the sulphide bearing veins, the sulphides occur as disseminations with medium crystal sizes. The quartz crystals that show undulatory extinction are aligned suggesting a post deformation.

The barren veins (Figure $4 \mathrm{~b}$ ) are characterized by oblique joints. Barren veins vary from few centimeter to $8 \mathrm{~m}$ wide with strike values ranging from $\mathrm{N} 20 \mathrm{E}$ to $\mathrm{N} 175 \mathrm{E}$ (mean strike of N97E). The dip of these veins ranges from $21^{\circ}$ to $74^{\circ}$ to the NW or the SE and E or W directions. Most of these veins are massive with very minor fractures on their surfaces. Structural data of these veins shows that the veins in the prospected area are variably oriented; however the N-S and ENE - WSW trends appear to be the dominant ones (Figure 6a-c)

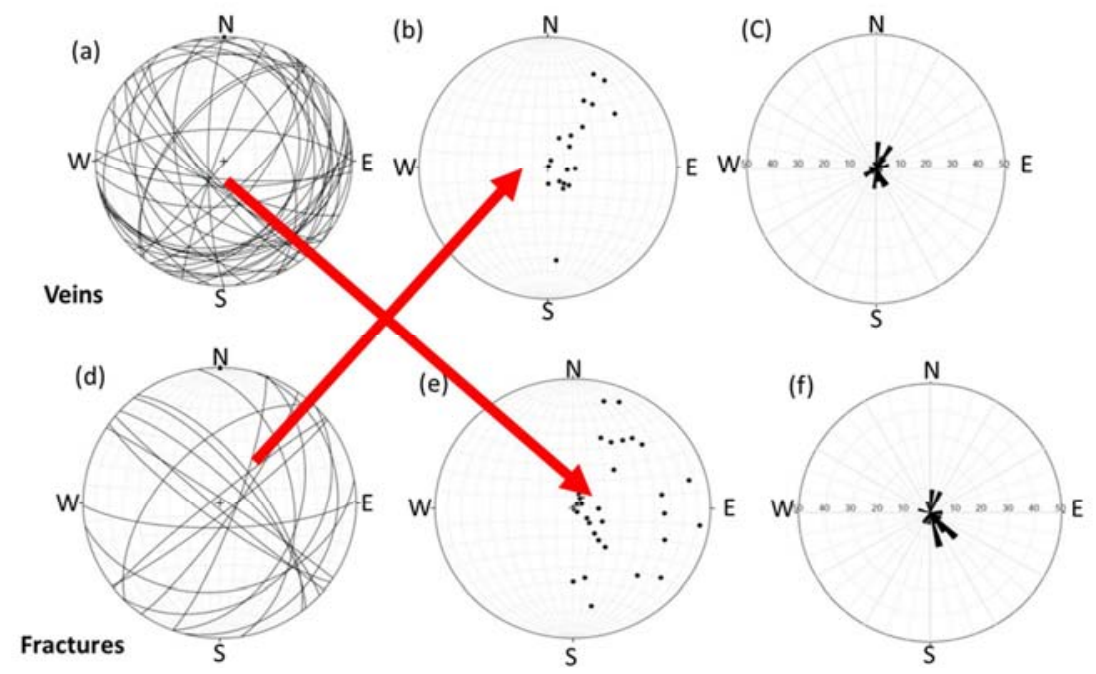

Figure 6. $\beta, \pi$, and Rose diagrams of veins and fractures in the Belikombone gold district. $a=\beta$ diagram of veins, $b=\pi$ diagram of veins, $c=$ Rose diagram of veins, $d=\beta$ diagram of fractures, $e=\pi$ diagram of fractures and $f=$ Rose diagram of fractures.

In this area most fracture surfaces have an average dip of $56^{\circ}$ predominantly to the west with minor displacement which crosscut the quartz veins and the fractures are parallel (NE-SW). Stereoplots ( $\beta$-diagrams and $\pi$-diagrams) show that the fracture surfaces are variably oriented (Figures 6d and 6e). As a whole, two principal sets of fractures have been recorded over the prospect: the N045089E and N030-041W defining two broad directions for this deformation including NE-SW and NW-SE respectively (Figure 6f).

\subsection{Geochemistry of Quartz, Veins}

The whole rock geochemical composition of quartz veins is shown in Table 1. In mineralized veins, the concentration of $\mathrm{Si}_{2} \mathrm{O}$ ranges from 83.54 to $99.43 \mathrm{wt} \%, \mathrm{Ti}_{2} \mathrm{O}$ from 0.003 to $0.264 \mathrm{wt} \%, \mathrm{Al}_{2} \mathrm{O}_{3}$ from 0.1 to $8.96 \mathrm{wt} \%, \mathrm{Fe}_{2} \mathrm{O}_{3}$ from 0.11 to $6.26 \mathrm{wt} \%, \mathrm{Mn}_{2} \mathrm{O}$ from 0.002 to $0.557 \mathrm{wt} \%, \mathrm{P}_{2} \mathrm{O}_{5}$ from 0.006 to $0.19 \mathrm{wt} \%, \mathrm{~K}_{2} \mathrm{O}$ from 0.01 to $0.075 \mathrm{wt} \%, \mathrm{Na}_{2} \mathrm{O}$ from 0.01 to $0.56 \mathrm{wt} \%, \mathrm{CaO}$ from 0.022 to $0.286 \mathrm{wt} \%$, $\mathrm{MgO}$ from 0.02 to $1.74 \mathrm{wt} \%, \mathrm{ClO}$ from 0.006 to $0.045 \mathrm{wt} \%$.

Table 1. Whole-rock ICP-MS analyses of quartz vein samples.

\begin{tabular}{|c|c|c|c|c|c|c|c|c|c|c|}
\hline \multirow{2}{*}{$\begin{array}{l}\text { Sample types } \\
\text { Sample names }\end{array}$} & \multicolumn{4}{|c|}{ Mineralized samples } & \multicolumn{6}{|c|}{ Barren samples } \\
\hline & QV01 & QV02 & QV05 & QV08 & QV03 & QV04 & QV06 & QV07 & QZT & SCH \\
\hline \multicolumn{11}{|c|}{ Major elements (\%) } \\
\hline $\mathrm{Ti}_{2} \mathrm{O}$ & 0.26 & 0.05 & 0.01 & 0.00 & 0.03 & 0.01 & 0.00 & 0.14 & 0.00 & 0.10 \\
\hline $\mathrm{Al}_{2} \mathrm{O}_{3}$ & 8.96 & 1.49 & 2.23 & 0.27 & 0.94 & 0.34 & 0.10 & 0.90 & 0.29 & 13.68 \\
\hline $\mathrm{Fe}_{2} \mathrm{O}_{3}$ & 3.56 & 6.26 & 2.59 & 0.11 & 0.66 & 0.13 & 0.21 & 3.12 & 0.14 & 1.09 \\
\hline $\mathrm{MgO}$ & 1.74 & 0.02 & 1.23 & 0.02 & 0.03 & 0.02 & 0.02 & 0.36 & 0.02 & 0.08 \\
\hline $\mathrm{CaO}$ & 0.29 & 0.02 & 0.23 & 0.03 & 0.04 & 0.03 & 0.06 & 0.13 & 0.03 & 0.36 \\
\hline $\mathrm{Na}_{2} \mathrm{O}$ & 0.56 & 0.01 & 0.01 & 0.01 & 0.01 & 0.01 & 0.01 & 0.01 & 0.01 & 3.41 \\
\hline $\mathrm{K}_{2} \mathrm{O}$ & 0.02 & 0.06 & 0.03 & 0.08 & 0.03 & 0.10 & 0.01 & 0.02 & 0.09 & 5.81 \\
\hline $\mathrm{P}_{2} \mathrm{O}_{5}$ & 0.01 & 0.19 & 0.17 & 0.01 & 0.01 & 0.01 & 0.01 & 0.10 & 0.01 & 0.03 \\
\hline $\mathrm{ClO}$ & 0.05 & 0.01 & 0.01 & 0.01 & 0.02 & 0.01 & 0.02 & 0.01 & 0.02 & 0.01 \\
\hline
\end{tabular}




\begin{tabular}{|c|c|c|c|c|c|c|c|c|c|c|}
\hline \multirow{2}{*}{$\begin{array}{l}\text { Sample types } \\
\text { Sample names }\end{array}$} & \multicolumn{4}{|c|}{ Mineralized samples } & \multicolumn{6}{|c|}{ Barren samples } \\
\hline & QV01 & QV02 & QV05 & QV08 & QV03 & QV04 & QV06 & QV07 & QZT & SCH \\
\hline \multicolumn{11}{|c|}{ Major elements (\%) } \\
\hline Total & 99.97 & 99.83 & 99.91 & 99.97 & 99.99 & 100.03 & 99.96 & 99.92 & 99.99 & 99.82 \\
\hline As & 9.60 & 9.70 & 4.20 & 2.50 & 0.40 & 10.70 & 1.50 & 1.20 & 0.30 & 0.60 \\
\hline $\mathrm{Au}$ & 25.00 & 4.30 & 0.50 & 3.70 & 0.20 & 0.20 & 0.20 & 0.20 & 0.20 & 0.20 \\
\hline $\mathrm{Ag}$ & 0.01 & 0.22 & 0.64 & 0.04 & 0.06 & 0.51 & 2.03 & 0.25 & 0.02 & 0.03 \\
\hline $\mathrm{Ba}$ & 10.00 & 10.00 & 10.00 & 10.00 & 10.00 & 10.00 & 10.00 & 10.00 & 10.00 & 10.00 \\
\hline Co & 10.70 & 27.30 & 4.10 & 1.10 & 1.50 & 0.30 & 2.50 & 1.20 & 1.00 & 1.30 \\
\hline $\mathrm{Hf}$ & 0.05 & 0.13 & 0.70 & 0.32 & 0.09 & 0.16 & 0.66 & 0.66 & 0.27 & 0.19 \\
\hline Mo & 0.50 & 1.00 & 0.30 & 0.20 & 0.20 & 0.20 & 0.30 & 0.20 & 0.20 & 0.20 \\
\hline $\mathrm{Rb}$ & 0.10 & 0.20 & 0.20 & 0.80 & 0.30 & 0.20 & 1.00 & 0.40 & 2.00 & 0.10 \\
\hline $\mathrm{Sb}$ & 0.39 & 0.30 & 0.17 & 0.12 & 0.26 & 0.18 & 0.16 & 0.16 & 0.25 & 0.13 \\
\hline $\mathrm{Sc}$ & 0.10 & 0.10 & 0.20 & 0.10 & 0.10 & 0.10 & 0.10 & 0.10 & 0.10 & 0.10 \\
\hline $\mathrm{Ta}$ & 0.01 & 0.01 & 0.01 & 0.01 & 0.01 & 0.01 & 0.01 & 0.01 & 0.01 & 0.01 \\
\hline Th & 0.20 & 0.20 & 0.20 & 0.20 & 0.20 & 0.20 & 0.20 & 0.20 & 0.70 & 0.20 \\
\hline U & 0.05 & 0.05 & 0.05 & 0.07 & 0.05 & 0.05 & 0.05 & 0.08 & 0.06 & 0.05 \\
\hline W & 0.06 & 0.05 & 0.05 & 0.05 & 0.05 & 0.05 & 0.15 & 0.05 & 0.05 & 0.05 \\
\hline $\mathrm{Zn}$ & 43.00 & 9.00 & 6.00 & 5.00 & 7.00 & 4.00 & 3.00 & 8.00 & 4.00 & 12.00 \\
\hline $\mathrm{Zr}$ & 0.50 & 0.50 & 0.50 & 0.50 & 0.60 & 0.50 & 0.90 & 0.50 & 0.80 & 0.50 \\
\hline $\mathrm{Cu}$ & 1.60 & 5.30 & 3.50 & 22.80 & 9.60 & 20.50 & 12.90 & 8.60 & 33.80 & 27.40 \\
\hline $\mathrm{Pb}$ & 14.00 & 2.80 & 1.10 & 0.40 & 1.80 & 0.20 & 0.60 & 2.00 & 2.40 & 1.20 \\
\hline $\mathrm{Cr}$ & 727.00 & 42.00 & 51.00 & 53.00 & 605.00 & 34.00 & 725.00 & 29.00 & 429.00 & 547.00 \\
\hline $\mathrm{Ni}$ & 21.10 & 44.60 & 8.00 & 4.60 & 5.80 & 2.30 & 7.30 & 5.10 & 3.80 & 5.20 \\
\hline $\mathrm{Sr}$ & 0.90 & 1.00 & 1.00 & 1.00 & 2.00 & 0.30 & 1.00 & 3.30 & 1.70 & 0.80 \\
\hline V & 2.00 & 1.00 & 1.00 & 1.00 & 2.00 & 1.00 & 2.00 & 1.00 & 1.00 & 1.00 \\
\hline $\mathrm{Nb}$ & 0.09 & 0.05 & 0.05 & 0.05 & 0.11 & 0.05 & 0.07 & 0.05 & 0.06 & 0.08 \\
\hline $\mathrm{Mn}$ & 0.09 & 1.44 & 3.98 & 0.31 & 0.47 & 2.16 & 7.12 & 5.45 & 0.12 & 0.42 \\
\hline $\mathrm{La}$ & 0.50 & 2.20 & 1.30 & 84.60 & 1.10 & 7.80 & 3.30 & 18.30 & 51.90 & 49.40 \\
\hline $\mathrm{Ce}$ & 0.06 & 0.06 & 0.43 & 1.51 & 0.51 & 0.48 & 0.10 & 0.78 & 4.70 & 0.84 \\
\hline $\operatorname{Pr}$ & 11.40 & 11.80 & 0.92 & 0.32 & 19.25 & 4.24 & 0.46 & 1.91 & 0.56 & 0.06 \\
\hline $\mathrm{Nd}$ & 0.20 & 2.20 & 1.50 & 71.00 & 1.50 & 7.40 & 3.50 & 15.90 & 44.10 & 43.00 \\
\hline $\mathrm{Sm}$ & 0.20 & 0.20 & 0.20 & 0.20 & 0.20 & 0.20 & 0.20 & 0.20 & 0.20 & 0.20 \\
\hline $\mathrm{Eu}$ & 0.50 & 1.00 & 0.30 & 0.20 & 0.20 & 0.20 & 0.30 & 0.20 & 0.20 & 0.20 \\
\hline $\mathrm{Gd}$ & 5.87 & 5.86 & 0.56 & 0.61 & 10.85 & 3.14 & 0.09 & 1.44 & 0.57 & 0.08 \\
\hline $\mathrm{Tb}$ & 0.04 & 0.09 & 0.05 & 0.02 & 0.01 & 0.01 & 0.03 & 0.01 & 0.01 & 0.01 \\
\hline Dy & 0.08 & 0.48 & 0.18 & 8.33 & 0.56 & 1.06 & 0.36 & 3.77 & 4.63 & 4.75 \\
\hline Y & 0.05 & 0.05 & 0.15 & 0.15 & 0.08 & 0.05 & 0.06 & 0.44 & 0.36 & 0.07 \\
\hline Но & 0.01 & 0.11 & 0.04 & 1.53 & 0.10 & 0.24 & 0.11 & 0.73 & 0.98 & 0.95 \\
\hline $\mathrm{Er}$ & 0.04 & 0.32 & 0.11 & 4.48 & 0.31 & 0.76 & 0.34 & 1.90 & 2.91 & 2.71 \\
\hline $\mathrm{Tm}$ & 0.01 & 0.03 & 0.01 & 0.64 & 0.04 & 0.11 & 0.04 & 0.27 & 0.48 & 0.41 \\
\hline $\mathrm{Yb}$ & 0.03 & 0.04 & 0.03 & 0.04 & 0.01 & 0.01 & 0.05 & 0.01 & 0.01 & 0.01 \\
\hline $\mathrm{Lu}$ & 0.09 & 0.02 & 0.01 & 0.01 & 0.01 & 0.01 & 0.01 & 0.02 & 0.01 & 0.01 \\
\hline$\Sigma$ REE & 19.08 & 24.46 & 5.79 & 173.64 & 34.73 & 25.71 & 8.95 & 45.88 & 111.62 & 102.70 \\
\hline$\Sigma$ LREE & 18.73 & 23.32 & 5.21 & 158.44 & 33.61 & 23.46 & 7.95 & 38.73 & 102.23 & 93.78 \\
\hline$\Sigma$ HREE & 0.35 & 1.14 & 0.58 & 15.20 & 1.12 & 2.25 & 1.00 & 7.15 & 9.39 & 8.92 \\
\hline$\Sigma$ LREE/ $\Sigma$ HREE & 53.51 & 20.46 & 8.98 & 10.42 & 30.01 & 10.43 & 7.95 & 5.42 & 10.89 & 10.51 \\
\hline $\mathrm{K} / \mathrm{Rb}$ & 0.24 & 0.32 & 0.13 & 0.09 & 0.11 & 0.52 & 0.01 & 0.06 & 0.04 & 58.12 \\
\hline $\mathrm{K} / \mathrm{Ba}$ & 0.00 & 0.01 & 0.00 & 0.01 & 0.00 & 0.01 & 0.00 & 0.00 & 0.01 & 0.58 \\
\hline $\mathrm{Ba} / \mathrm{Rb}$ & 100.00 & 50.00 & 50.00 & 12.50 & 33.33 & 50.00 & 10.00 & 25.00 & 5.00 & 100.00 \\
\hline $\mathrm{Rb} / \mathrm{Sr}$ & 0.11 & 0.20 & 0.20 & 0.80 & 0.15 & 0.67 & 1.00 & 0.12 & 1.18 & 0.13 \\
\hline $\mathrm{Co} / \mathrm{Ni}$ & 0.51 & 0.61 & 0.51 & 0.24 & 0.26 & 0.13 & 0.34 & 0.24 & 0.26 & 0.25 \\
\hline $\mathrm{Hf} / \mathrm{Sm}$ & 0.25 & 0.65 & 3.50 & 1.60 & 0.45 & 0.80 & 3.30 & 3.30 & 1.35 & 0.95 \\
\hline $\mathrm{Nb} / \mathrm{La}$ & 0.18 & 0.02 & 0.04 & 0.00 & 0.10 & 0.01 & 0.02 & 0.00 & 0.00 & 0.00 \\
\hline Y/Ho & 5.00 & 0.45 & 3.75 & 0.10 & 0.80 & 0.21 & 0.55 & 0.60 & 0.37 & 0.07 \\
\hline $\mathrm{Th} / \mathrm{U}$ & 4.00 & 4.00 & 4.00 & 2.86 & 4.00 & 4.00 & 4.00 & 2.50 & 11.67 & 4.00 \\
\hline$(\mathrm{La} / \mathrm{Yb}) \mathrm{n}$ & 11.32 & 37.36 & 29.44 & 1436.77 & 74.73 & 529.87 & 44.84 & 1243.16 & & \\
\hline$(\mathrm{La} / \mathrm{Sm}) \mathrm{n}$ & 1.56 & 6.87 & 4.06 & 264.15 & 3.43 & 24.35 & 10.30 & 57.14 & & \\
\hline$(\mathrm{Gd} / \mathrm{Yb}) \mathrm{n}$ & 158.30 & 118.53 & 15.10 & 12.34 & 877.81 & 254.04 & 1.46 & 116.50 & & \\
\hline
\end{tabular}


In the barren quartz veins, most of the major elements have concentrations less than $0.01 \mathrm{wt} \%$, except for $\mathrm{Al}_{2} \mathrm{O}_{3}$ $\mathrm{Fe}_{2} \mathrm{O}_{3}$ and $\mathrm{CaO}$ which have higher concentrations. However, these veins have high silica concentrations. Therefore, the quartz veins are highly siliceous. $\mathrm{Al}_{2} \mathrm{O}_{3}$ content varies from 0.1 to $8.96 \mathrm{wt} \%, \mathrm{Fe}_{2} \mathrm{O}_{3}$ ranges from 0.13 to $6.26 \mathrm{wt} \%$ while $\mathrm{MgO}$ varies from 0.02 to $1.74 \mathrm{wt} \%$. The concentrations of other major oxides are very low.

The mineralized veins (QV01, QV02, QV05, and QV08) contain $\mathrm{Au}$ from 0.50 to $25 \mathrm{ppm}$, while the quartz veins considered barren contain $0.20 \mathrm{ppm} \mathrm{Au}$. It is worth noting that samples QV01 (25 ppm of Au) and QV02 (4.30 ppm Au) were recovered from the quartz veins that outcropped on the surface and are about 10 meters apart. The gold concentration in the barren veins exceed the background (5ppb) and the Clarke's concentration (4ppb) in the study area. The low concentration of $\mathrm{Au}$ in the barren quartz veins shows that gold mineralization is not evenly distributed throughout the area.

The concentrations of other trace elements in the mineralized veins such as $\mathrm{Zn}, \mathrm{P}, \mathrm{Ni}, \mathrm{V}, \mathrm{Sr}, \mathrm{Pb}, \mathrm{U}, \mathrm{Rb}, \mathrm{As}$ and $\mathrm{Cr}$ varies from 3.0 to $43 \mathrm{ppm}, 10-40 \mathrm{ppm}, 4.6-44.6 \mathrm{ppm}, 1$ 2ppm, 0.92ppm, 0.4-14ppm, 0.05-0.07ppm, 0.1-1ppm, 0.4$9.7 \mathrm{ppm}$ and $29-727 \mathrm{ppm}$ respectively. The concentrations of $\mathrm{B}, \mathrm{Ba}, \mathrm{Ta}$ and $\mathrm{Tl}$ are the quite equivalent in both mineralized and barren quartz veins. The concentration of As in the quartz veins ranges from $0.30 \mathrm{ppm}$ to $10.70 \mathrm{ppm}$ and it is worth noting that As show positive correlation with $\mathrm{Au}$ in samples with high Au concentration. The concentrations of $(\mathrm{Co}+\mathrm{Ni}+\mathrm{Cu}+\mathrm{Zn})-\mathrm{Fe}-\mathrm{Mn}$ in quartz veins were plotted on a ternary diagram differentiate between submarine hydrothermal and hydrogenous deposits [16]. The data plotted indicate that the quartz veins bearing gold are of hydrothermal origin (Figure 7). However only the concentration of As (4ppm) exceeded the backgrounds limit for non-mineralized veins. The concentration of $\mathrm{Pb}$ was below the limit (20.7 ppm).

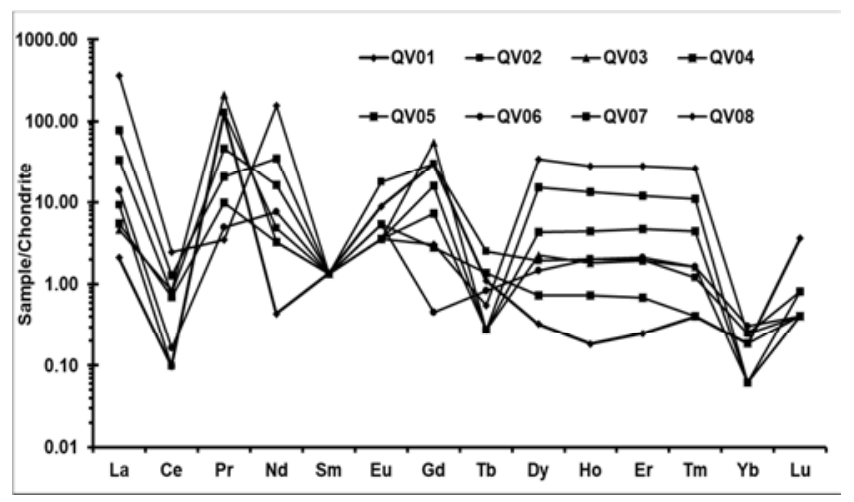

Figure 7. Chondrite - normalized REE patterns of the Quartz vein samples.

The SREE varies from 5.79 to 173.64 in the analyzed quartz veins (Table 1) with notable LREE (range from 5.21 to 158.44) and HREE (range from 0.35 to 15.20) fractionation, while the quartzite and schist samples content is 111.62 and 102.70 respectively. The $(\mathrm{La} / \mathrm{Yb})_{\mathrm{N}},(\mathrm{La} / \mathrm{Sm})_{\mathrm{N}}$ and $(\mathrm{Gd} / \mathrm{Yb})_{\mathrm{N}}$ values ranges from $11.32-1436.77,1.56-$ 264.15 and $1.46-254.04$ respectively. Chondrite normalized plots of the REE in the quartz veins is shown in Figure 8. The normalized pattern shows negative $\mathrm{Ce}, \mathrm{Nd}, \mathrm{Tb}$ and $\mathrm{Yb}$ anomalies with positive $\mathrm{La}, \mathrm{Pr}, \mathrm{Ce}$ and $\mathrm{Gd}$ anomalies.

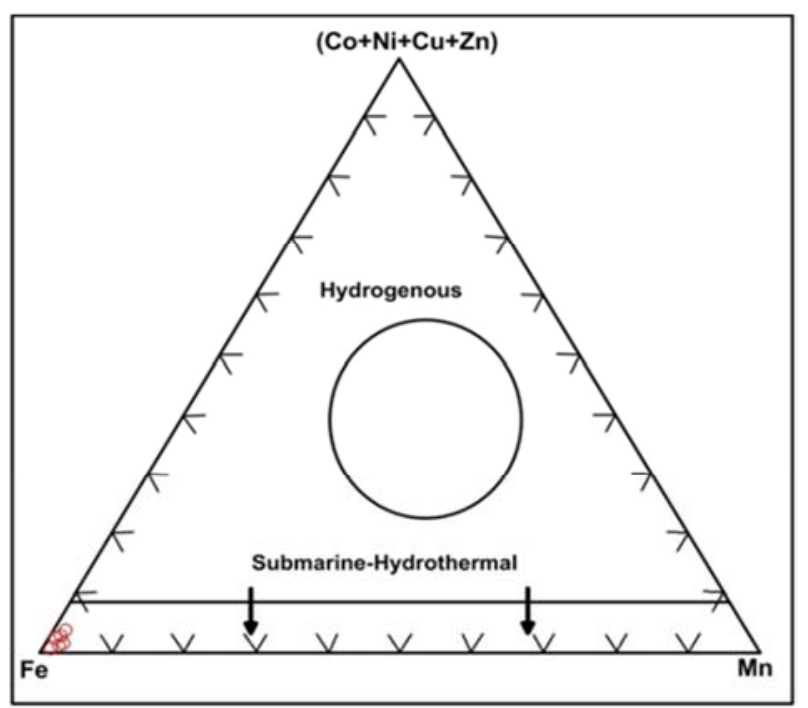

Figure 8. (Co $+\mathrm{Ni}+\mathrm{Cu}+\mathrm{Zn})-\mathrm{Fe}-\mathrm{Mn}$ ternary plot of quartz veins used to differentiate submarine and hydrothermal and hydrogenous deposits.

\section{Discussion}

In many gold fields, gold is hosted by quartz veins [8, 17] and such is the case with the Belikombone gold prospect. The mineralized quartz veins observed showed cross-cutting relationships implying different stages of vein emplacement in the area. The fact that the mineralized quartz veins crosscut the schist in the area also indicate epigenetic style of mineralization. The poles to quartz veins plotted on the stereographic projection and rose diagrams of the quartz veins show that the quartz veins in the schists are generally trending NW-SE (Figure 6), and are concordant to the foliations in the schist, which also have a NW-SE trend. Studies within the Betare Oya gold district [15] to which Belikombone belong, generally trend in the NW-SE direction. The N-S and ENE - WSW trends being the dominating ones for the veins and thus gold mineralization within the Belikombone prospect is structurally controlled. The concordant nature of the quartz vein in this area to the foliation in the schist country rock indicates that the emplacement of the quartz was syngenetic. The emplacement of the hydrothermal quartz veins in the Belikombone prospect can globally be related to the NE-SW trending structures Lom basin structure (Figure 1), which provided pathways for hydrothermal fluid flow [18]. Hydrothermal fluids are controlled by a wide variety of pre-existing structures particularly foliations, shear zones and fractures $[19,20]$ and such structural relationships are common in orogenic zones, particularly in shear related deformation [21, 22]. Subsequent plutonism or metamorphism may cause the reactivation of these structures [23]. 
The mineralogy of the studied quartz veins is dominantly composed of quartz \pm sulphides, some sericite and iron oxides in the form of hematite or magnetite (mostly as fracture infill). According to Wegner et al. [24] massive quartz veins are formed during multiple episodes of vein opening, fluid interaction and vein sealing events, while brecciated quartz veins [25] are the result of alteration of earlier formed veins and represent a later event. The differences in terms of texture and mineralogy of the massive and brecciated quartz in the area suggest that they were formed during different hydrothermal events. The fact that most mineralized quartz veins are brecciated shows that hydro-fracturing (fluids assisted fracturing) is likely to have been the process that led to the formation of the breccias and was triggered by variations in fluid pressure [26] and according to Craw et al. [27], breccias are indicators of brittle deformation and have been considered typical to be of shallowly-formed veins. This could also be seen in the Belikombone quartz veins and implies that the quartz veins were formed at shallow depths and probably associated with brittle deformation. Figure 9 summarized the mineral paragenesis of quartz vein containing gold obtained from the study area. The mineral sequence of the study area comprises initial host rock formation which later experienced fracturing. This is subsequently followed by the introduction of hydrothermal mineralizing fluid composing of quartz, gold, sulphide and magnetite. Some primary minerals like biotite and amphibole in the quartz veins were later altered to chlorite and sericite. The development of quartz, sericite, and pyrite alteration minerals in the quartz veins confirms that silicification, sericitization, and sulphidation processes are associated with gold mineralization.

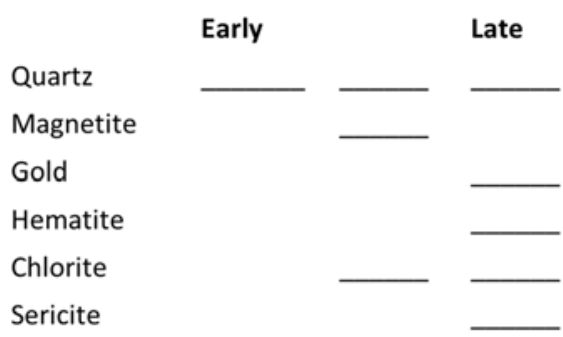

Figure 9. Summarized mineral paragenesis of quartz vein containing gold obtained from this study.

Gold concentrations in the Belikombone quartz veins vary considerably $(0.2-25.0 \mathrm{ppm})$. The concentration of gold in sample QV01 is quite high to qualify as a potential ore grade. Economic occurrence of gold generally consists of very small amounts of dispersed gold or gold-silver alloys. Even in the well-known ore of the Witwatersand deposit in South Africa, the average concentration of gold is only about $16000 \mathrm{ppb}$ [18]. Where there are considerable variations in gold concentrations, there is the possibility of an existence of high-grade ore shoots within a largely low-grade gold system [6]. Most quartz vein samples that have high gold content equally have high arsenic concentration and the appreciable As signature further confirms that the quartz veins were formed in an orogenic setting [28]. The association of $\mathrm{Au}$ with As therefore implies that As could be utilized as an effective geochemical pathfinder element for gold exploration in the study area. The concentration of $\mathrm{Sb}(0.12$ to $0.39 \mathrm{ppm}$ ) is below the minimum concentration of $0.59 \mathrm{ppm}$ in unmineralized materials $(1 \mathrm{ppm})$ in all the samples analyzed and it is known to be associated with gold deposit. $\mathrm{Au}, \mathrm{Ag}, \mathrm{As}, \mathrm{Sb}, \mathrm{Pb}, \mathrm{Zn}, \mathrm{W}$, and Mo in quartz veins and host rocks display great positive correlations which are obvious between $\mathrm{Au}$ and $\mathrm{Ag}, \mathrm{Pb}, \mathrm{Zn}$, and $\mathrm{Sb}$ with $\mathrm{Au}$, suggesting that the enrichment of $\mathrm{Au}, \mathrm{Ag}, \mathrm{As}, \mathrm{Sb}, \mathrm{Pb}$, and $\mathrm{Zn}$ may have synchronously taken place. In addition, hightemperature elements such as $\mathrm{W}$ and Mo show positive correlations with Au. Anomalies of $\mathrm{W}$ and Mo are often correlated with the activity of magmatic hydrothermal fluids [29]. The trace element composition of quartz veins possibly reflects the element features of ore-forming fluids [29]. It can be concluded that ore-forming fluids of the Belikombone deposit were enriched in sulphophile elements such as $\mathrm{Au}$, $\mathrm{Ag}, \mathrm{As}, \mathrm{Sb}, \mathrm{Pb}$ and $\mathrm{Zn}$ and simultaneously concentrated hightemperature elements such as $\mathrm{W}$ and Mo. At the same time, enrichment in $\mathrm{W}$ and Mo reflects multi-stage mineralization or overprinting of magmatic hydrothermal fluids.

Recent studies suggest that hydrothermal fluids enriched in $\mathrm{Cl}$ can effectively concentrate light REE but deplete HFSE, whose values of $\mathrm{Hf} / \mathrm{Sm}, \mathrm{Nb} / \mathrm{La}$ and $\mathrm{Th} / \mathrm{La}$ are usually less than 1; and hydrothermal fluids enriched in $\mathrm{F}$ can synchronously concentrate light REE and HFSE, whose values of $\mathrm{Hf} / \mathrm{Sm}$, $\mathrm{Nb} / \mathrm{La}$ and $\mathrm{Th} / \mathrm{La}$ are usually more than 1 [30]. According to the analytical results (Table 1), quartz veins and host rocks of the Belikombone gold prospect are obviously enriched in light REE and universally depleted in HFSE, with the values of $\mathrm{Hf} / \mathrm{Sm}, \mathrm{Nb} / \mathrm{La}$ and $\mathrm{Th} / \mathrm{La}$ being less than 1 . This suggests that the hydrothermal fluids responsible for the emplacement of quartz veins in the studied area were enriched in $\mathrm{Cl}$.

Field and petrographic evidences from the Belikombone area indicate the occurrence of gold bearing quartz veins hosted in schists, granites and gneisses. Similar observations elsewhere e.g. Bini Yauri [31] and Maru [18] concluded that magmatic fluid or recirculated groundwater may be part of the ore constituents at some stage of vein evolution and accompanied alteration. The ore fluid may largely have been derived from fracturing and metamorphic dewatering [31] of the host rocks. There are very few auriferous Archean greenstone belts that contain gold provinces without nearby intrusions of roughly the same age. Whether or not any of these igneous bodies are the source of fluids and metals that become a part of the gold-forming system is often a highly debated issues; the other obvious scenario is that both melts and fluid may be product of the same deep-crustal or even mantle generated, thermal event $[20,32]$.

\section{Conclusion}

Au-bearing quartz veins in the Belikombone area are confined to major NW-SE orientations in schists and N-S and ENE - WSW in other host rocks. These veins are characterized by partially and completely filled fractures and foliation planes. This therefore constitute the main 
mineralization style within the area. Both the mineralized and non-mineralized (barren) quartz veins varieties occur in this area. The studied quartz veins are dominantly composed of quartz \pm sulphides, some sericite and iron oxides in the form of hematite or magnetite and were formed during different hydrothermal events. Hydro-facturing is likely to have been the process that led to the formation of brecciaed veins.

The investigated veins show evidence of multiphase deformation as indicated by the mineralogical, textural and cross-cutting relationships among veins. The emplacement of the quartz veins is associated with $\mathrm{D}_{2}$ deformation as indicated by similarity in the generalized strike direction of quartz veins and host rocks. It postdates regional metamorphism and fracturing. This structural setting suggest that the emplacement of gold mineralization occurred during the late Pan African orogeny. The quartz veins have simple mineralogy dominated by quartz and sulphides. The main alteration types are silification, sericitization and sulphidation processes.

\section{Conflict of Interests}

The authors declare that there is no conflict of interests regarding the publication of this paper.

\section{Acknowledgements}

The authors extend thanks to the anonymous reviewers whose pertinent comments assisted us to improve on the manuscript, and to the Engineering Science editorial team for assistance and handling of the manuscript.

\section{References}

[1] Catheline, M., Marignac, C., Boiron, M. C., Poty, B. (1991). Herynian $\mathrm{Au}$ bearing quartz veins from Western Europe: the "shear zone model" revisited. Proceeding of Au. Brazil Balkema 91, 115-119.

[2] Simard, M., Bedoin, G., Bernard, J., Hupé, A. (2006). Metallogeny of the Mont-de-L'Aigle IOCG deposit, Gaspé Peninsula, Québec, Canada. Mineralium Deposita 41, 607-636.

[3] Kreuzer, O. P. (2006). Textures, paragenesis and wall rock alteration of lode $\mathrm{Au}$ deposits in the Charter Towers district, North Queensland: implication for the conditions of ore formation. Mineralium Deposita 40, 639-663.

[4] Junks, A. J., Cooke, D. R. (2007). Geological and structural controls on Au mineralization in the Tanami district Northern Territory 42, 107-126.

[5] Freyssinet, P. H., Lecomte, P., Edimo, A. (1989). Dispersion of gold and base metals in the Mborguene lareitic profile, East Cameron. Journal of geochemical exploration, 32, 99-116.

[6] Suh, C. E., Lehmann B., Mafany, G. T. (2006). Geology and geochemical aspects of lode gold mineralization at DimakoMboscorro, SE Cameroon. Geochemistry: Exploration, Environment, Analysis, 6, 295-309.

[7] Suh, C. E. (2008). Sulphide microchemistry and hydrothermal fluid inclusion in quartz veins Batouri gold district (Southern
Cameroon). Journal of the Cameroon Academy of Science 8, 19-29.

[8] Embui, V. F., Omang, B. O., Che, V. B., Nforba, M. T., Suh E. C., (2013). Gold grade variation and strean sediment geochemistry of the Vaimba-Lidi drainage system, Northern Cameroon (West Africa). Natural Science, 5, 282-290.

[9] Mimba, E. M, Nforba, M. T., Suh, C. E. (2014). Geochemical Dispersion of Gold in Stream Sediments in the Paleoproterozoic Nyong Series, Southern Cameroon. Science Research. Vol. 2, No. 6, 155-165. https://doi:10.11648/j.sr.20140206.12.

[10] Stendal, H., Toteu, S. F., Frei, R., Penaye, J., Njel, U. O., Bassahak, J., Nni, J., Kankeu, B., Ngako, V., Hell, J. V. (2006). Provenance of rutile from the Yaoundé region, Neoproterozoic Pan-African belt in southern Cameroon (Central Africa). Journal of African Earth Sciences, 44, 443-458.

[11] Kwékam, M., Liégeois, J.-P., Njonfang, E., Affaton, P., Hartmann, G., Tchoua, F. (2010). Nature, origin and significance of the Fomopéa Pan-African high-K calc-alkaline plutonic complex in the Centraal African fold belt (Cameroon). Journal of African Earth Sciences, 57, 79-95.

[12] Toteu, S. F., Penaye, J., Djomani, Y. P. (2004). Geodynamic evolution of the Pan-African belt in central Africa with special reference to Cameroon. Canadian Journal of Earth Sciences, $41,73-85$.

[13] Toteu, S. F., Penaye, J., Deloule, E., Van Schmus, W. R., \&Tchameni, R., (2006). Diachronous evolution of volcanosedimentary basins north of the Congo craton: Insights from $\mathrm{U}-\mathrm{Pb}$ ion microprobe dating of zircons from the Poli, Lom and Yaoundé Groups (Cameroon). Journal of African Earth Sciences, 44, 428-442.

[14] Ngako, V., Affaton, P., Nnange, J. M., Njanko, T. (2003). PanAfrican tectonic evolution in central and southern Cameroon: transpression and transtension during sinistral shear movements. Journal of African Earth Sciences, 36, 207-214.

[15] Kankeu, B., Greiling, R. O., Nzenti, J. P. (2009). Pan-African strike-slip tectonics in eastern Cameroon-Magnetic fabrics (AMS) and structure in the Lom basin and its gneissic basement. Precambrian Research, 174, 258-272.

[16] Salem I. A., El-Shibiny N. H., Abdel Monsef M. (2016). Mineralogical and Geochemical Studies on Manganese Deposits at Abu Ghusun Area, South Eastern Desert, Egypt. Journal of Geography and Earth Sciences, 4 (2), 51-74. https://doi.org/10.15640/jges.v4n2a4.

[17] Pitfield, P. E. J., Campbell, D. G. (1996). Significance for gold exploration and structural styles of auriferous deposits in the Archean Bulawoyo-Bubi greenstone belt of Zimbabwe. Transaction Institution of Mining and Metallurgy, Section B, Applied Earth science, 105, 4152.

[18] Oke, S. A., Akinlolu. F., Dieter R. (2014). Mineralogical and Geochemical Characterization of Gold Bearing Quartz Veins and Soils in parts of Maru Schist Belt Area, Northwestern Nigeria. Journal of Geological Research, $1-17$, https://doi.org/10.1155/2014/314214.

[19] Groves, D. I., Goldfarb, R. J., Gebre-Mariam, M., Hagemann, S. G., \& Robert, F. (1998). Orogenic gold deposits: A proposed classification in the context of their crustal distribution and relationship to other gold deposit types. Ore Geology Reviews, 13, 7-27. 
[20] Yannah, M., Suh, C. E., Mboudou, G. M. M. (2015). Quartz veins characteristics and Au mineralization within the Batouri $\mathrm{Au}$ District, East Cameroon. Science Research, 3 (4), 137149. https://doi:10.11648/j.sr.20150304.12.

[21] Brito Neves, B. B., Van Schmus, W. R., Fetter, A. (2002). North western, Africa-north, east Brazil: major tectonic links and correlation problems. Journal of African Earth Sciences $34,275-278$.

[22] Vallance, J., Boiron, M. C., Catheline, M., Verlet, M., Marignac, C., (2004). The granitic hosted $\mathrm{Au}$ deposit of Moulin de Chéni (Saint Yrieix district, Massif Central France): petrography, structural, fluid inclusion and oxygen isotope constraints. Mineralium Deposita 39, 265-281. https://doi:10.1007/s00126-003-0396-6.

[23] Klein, E. L., Alves dos Santos, R., Fuzikawa, K., Angelica, R. S., (2001). Hydrothermal fluid evolution and structural control of the Guarim $\mathrm{Au}$ mineralization, Tapajos Province, Amazonian craton, Brazil. Mineralium Deposita 36, 149-164.

[24] Wagner, T., Boyce, A. J., Erzinger, J. (2010). Fluid-rock interaction during formation of metamorphic quartz veins: a REE and stable isotope study from the Rhenish Massif, Germany. American Journal of Science, 310, 645-682. https://doi.10.2475/07.2010.04.

[25] Cheong, S. (2000). General characteristics and structural evolution of metamorphic goldquartz veins in northwestern Nevada, U. S. A. Geoscience Journal 4, 135. https://doi.org/10.1007/BF02910133.

[26] Chauvet, A. (2019). Structural Control of Ore Deposits: The Role of Pre-Existing Structures on the Formation of
Mineralised Vein Systems. Minerals, 9 (1), 56. https://doi.org/10.3390/min9010056.

[27] Craw, D., Windle, S. J., Angus, P. V. (1999). Gold mineralization without quartz veins in a ductile - brittle shear zone, Macraes Mine, Otago Schist, New Zealand. Mineralium Deposita, 34, 382-394. https://DOI:10.1007/s001260050211.

[28] Robert F., Brommecker R., Bourneetal B. F. (2007). Models and exploration methods for major gold deposit types. In Proceeding of the 5th Decennial Internal Conference on Mineral Exploration (Exploration '07) Milkereit B. (Ed). 691 711.

[29] Liu, K., Yang, R., Chen, W., Liu, R., Tao, P. (2014). Trace element and REE geochemistry of the Zhewang gold deposit, southeastern Guizhou Province, China. Chini. J. Geochem. 33, 109-118. https://doi:10.1007/s11631-014-0665-3.

[30] Krneta S., Ciobanu C. L., Cook N. J., Ehrig K., KontonikasCharos A. (2017). Rare Earth Element Behaviour in Apatite from the Olympic Dam $\mathrm{Cu}-\mathrm{U}-\mathrm{Au}-\mathrm{Ag}$ Deposit, South

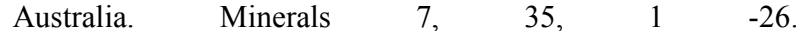
https://doi:10.3390/min7080135.

[31] Akande, S. O., Fakorede, O., Mucke, A. (1988). Geology and genesis of gold-bearing quartz veins at Bini Yauri and Okolom in the Pan-African domain of Western Nigeria. Geologie en Mijnbouw, 67 (1), 41-51.

[32] Goldfarb R. J., Baker T., Dube B., Groves D. I., Hart C. J. R., Gosselin P. (2005). Distribution, character and genesis of gold deposits in metamorphic terranes. In Economic Geology $100^{\text {th }}$ Anniversary Volume, Society of Economic Geologists, Littleton, Colo, USA. 407-450. 